\title{
POU3F2 wt Allele
}

National Cancer Institute

\section{Source}

National Cancer Institute. POU3F2 wt Allele. NCI Thesaurus. Code C98198.

Human POU3F2 wild-type allele is located in the vicinity of $6 q 16$ and is approximately $4 \mathrm{~kb}$ in length. This allele, which encodes POU domain, class 3, transcription factor 2 protein, plays a role in the regulation of both gene transcription and cell proliferation. 